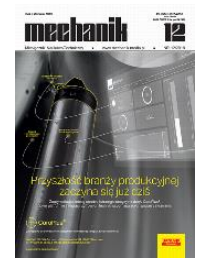

How to cite this article:

Authors: Jarosław Świtacz, Jarosław Bartnicki

Title of article: „Analysis of automotive fixing plate drawing process”

Mechanik, No. 12 (2018)

DOI: https://doi.org/10.17814/mechanik.2018.12.190

\title{
Analysis of automotive fixing plate drawing process
}

\author{
JAROSŁAW ŚWITACZ \\ JAROSŁAW BARTNICKI *
}

* Mgr inż. Jarosław Świtacz, jaroslaw.switacz@o2.pl - Katedra Komputerowego Modelowania i Technologii Obróbki Plastycznej, Politechnika Lubelska, Lublin, Polska

Dr hab. inż. Jarosław Bartnicki, j.bartnicki@pollub.pl, https://orcid.org/0000-0001-5906-9908 - Katedra Komputerowego Modelowania

i Technologii Obróbki Plastycznej, Politechnika Lubelska, Lublin, Polska

The paper deals with the drawing process of automotive fixing plates realized in progressive tools. Numerical analyses by means of FEM were done for chosen parts of the process. The distributions of effective stress, strain and load parameters were analyzed for realization of real process in practice. Good convergence between numerical results and final parts ones confirms very high applicability of FEM tools in these kinds of processes calculations.

KEYWORDS: progressive drawing tool, FEM

\section{Introduction}

There is a continuous progress in the construction of tools used in drawing processes. Due to the need to increase the efficiency of mass production, drawing tools are mainly made as progressive ones. Up to several tacts of the process are used in their construction.

Increasing the complexity of the drawing tools structure forced designers to study the possibility of forecasting the shapes of semi-finished and finished products in subsequent shaping tacts [1-3]. Optimization of the work parameters of these tools in terms of increasing the productivity while reducing the working time as well as material and energy consumption is the subject of a fierce competition between tool shops in many countries. Additional narrowing of the tolerance fields in the assessment of finished products made the use of numerical simulations almost indispensable [1-5].

Numerical simulation calculations, mainly using the finite element method (FEM), are now possible with several commercial software packages. Each of them has both advantages and disadvantages.

During the analysis of the car bracket drawing process, it was decided to perform numerical calculations in the Simufact Forming environment [6-9]. The assumed drawing tool structure consisting of six tacts, was expanded with additional operations related to minimizing the risk of sheet metal cracking during numerical simulations. The drawing tool structure outlined below is the target solution implemented in industrial conditions. Shape of the final product is shown in fig. 1.

\section{Drawing tool structure}

The progressive drawing tool, shown in fig. 2, intended for drawing the fixing plate, consists of nine tacts. In fig. 2 plates, punches, clamping pads and guide parts (guide posts and guide sleeves) are showed as well as short-circuit blocks and catches. The following were presented: plate, dies, guide sleeves, belt lifting and guiding elements, gutter, short-circuit blocks, catches and sheet feed sensor. Layout of the sheet metal strip is shown in fig. 3, while its sketch with separation of shaping zones - in fig. 4.

The drawing tool is divided into two parts. The first part consists of the first to the fourth tact and is shown in figs. 5-6. The second part is the tacts from the fifth to the ninth, shown in figs. 7-8. 


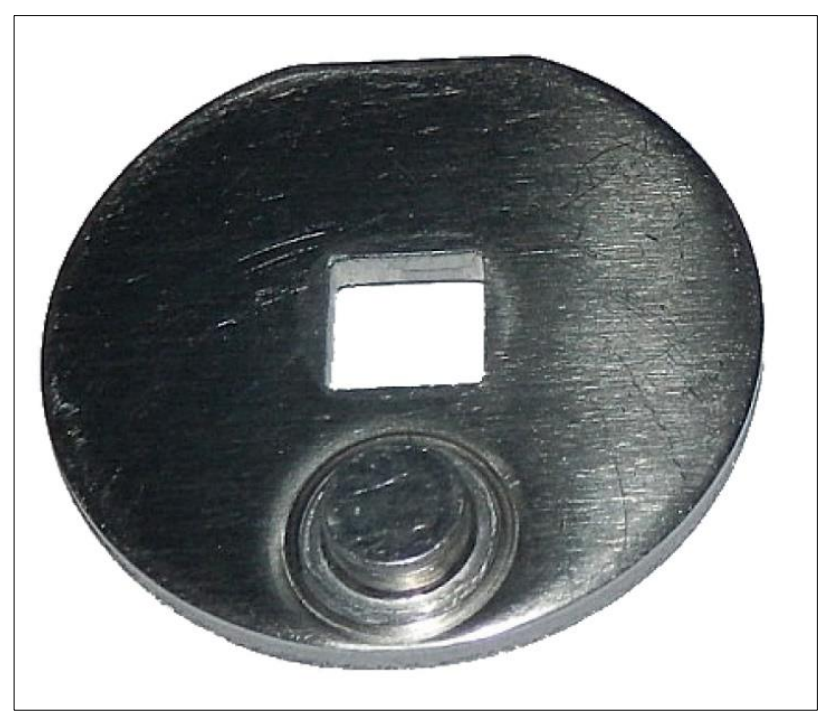

Fig. 1. Car bracket - final product

Fig. 2. Progressive drawing tool - upper part model with clamp and lower part model with visible guide strips

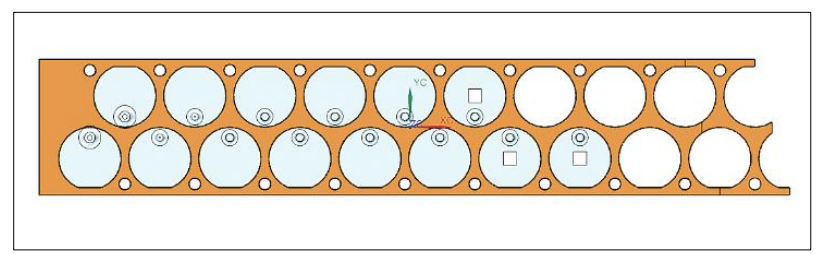

Fig. 3. Sheet metal strip model (layout)

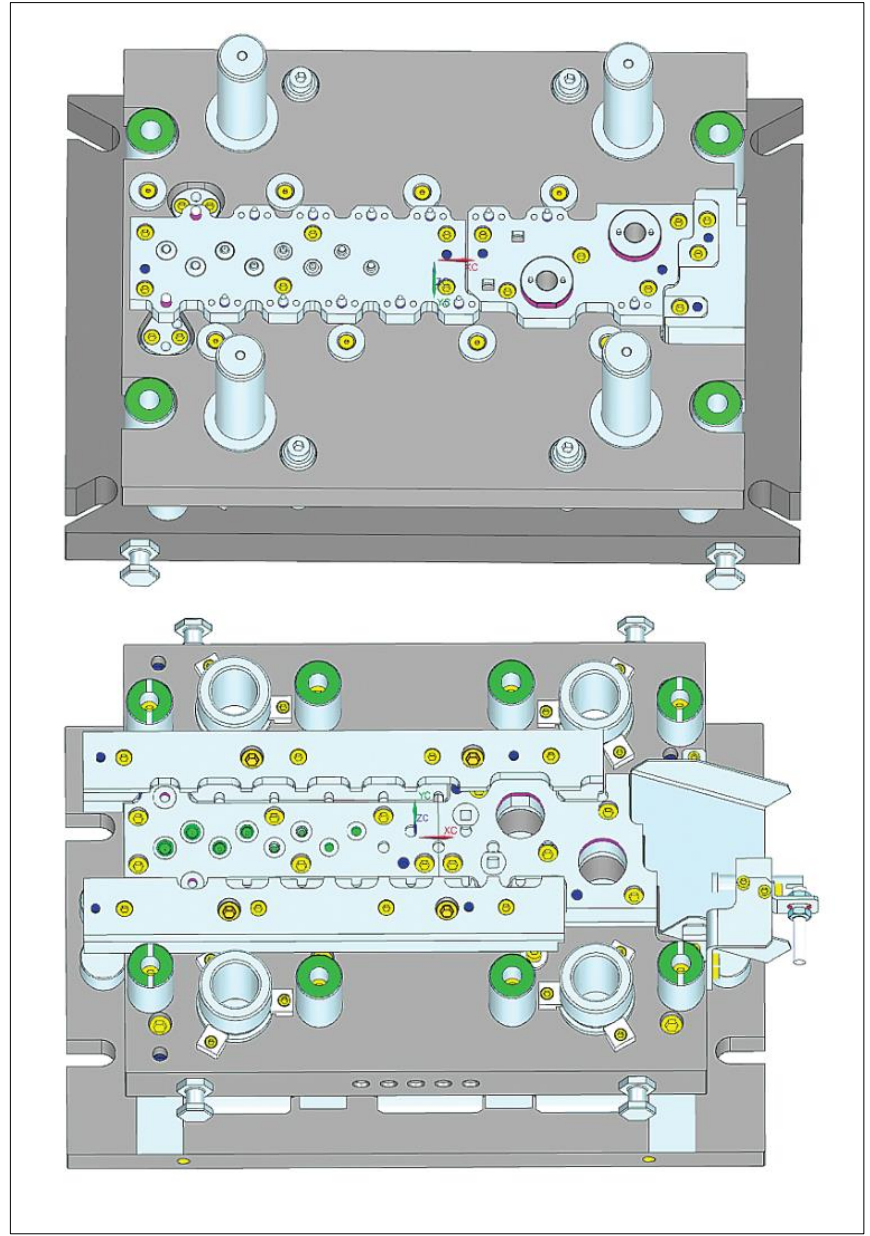

In the first tact, punching takes place under the pilots and pre-picking material for the drawing shown. In the second and third tacts, initial drawing is carried out, and in the fourth tact - the final drawing is performed. In the fifth tact, the square hole is punched, while in the sixth and eighth tacts, the whole product is cut out. The seventh tact is empty for constructional reasons. In the last tact, the waste is cut off.

The drawing tool was designed for a crank press. At the design stage, the threats of dimensional and shape deviations of the resulting semi-products were determined, as well as possibility of cracking the bottom in the crease. Numerical analysis allowed for determining the necessity of performing the drawing in four successive tacts (fig. 4).

The drawing tool was designed in the NX10 program, mainly in the Progressive Die Wizard module for designing the progressive drawing tools. This tool supports the design of a drawing tool and development of metal sheets in individual tacts, creating the so-called layout, i.e. a strip of metal sheet with the shape of the embossing in each tact.

The extrusion models in each tact were used to create models of shaping and trimming tools. The models were prepared for simulation in the NX program and exported to STL format.

Division of the drawing tool into individual tacts was made according to the following scheme:

- first tact - punching and drawing,

- second tact-drawing,

- third tact - drawing,

- fourth tact - additional drawing,

- fifth tact - punching,

- sixth tact - trimming,

- seventh tact - empty,

- eighth tact - trimming,

ninth tact - cutting off waste. 

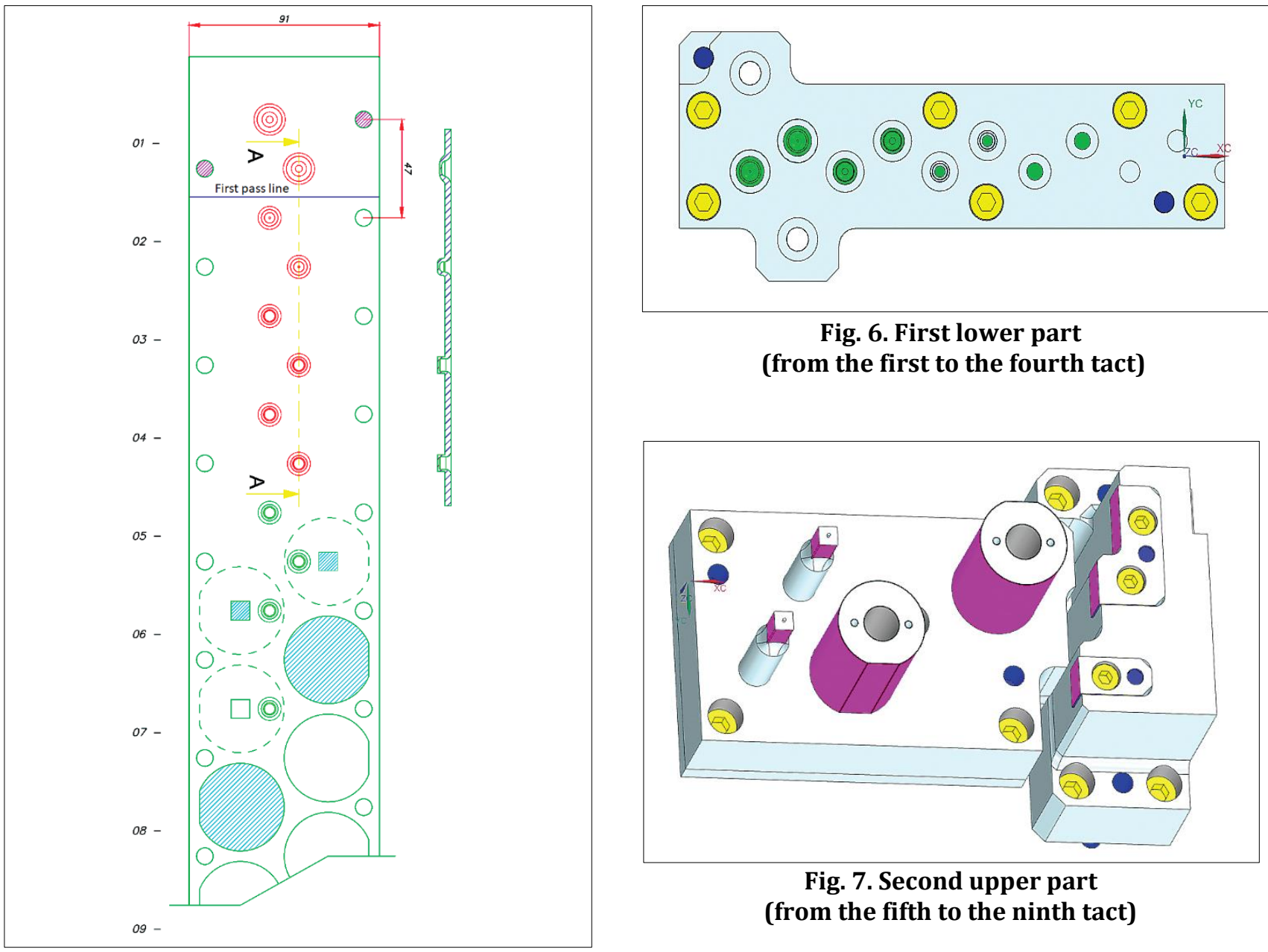

Fig. 6. First lower part

(from the first to the fourth tact)

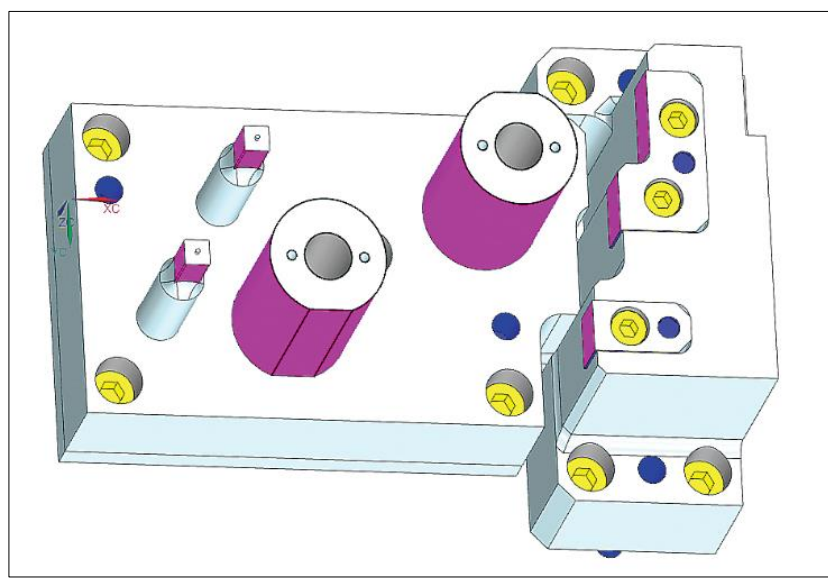

Fig. 7. Second upper part

(from the fifth to the ninth tact)

Fig. 4. Top view of sheet metal strip with extrusion after subsequent operations

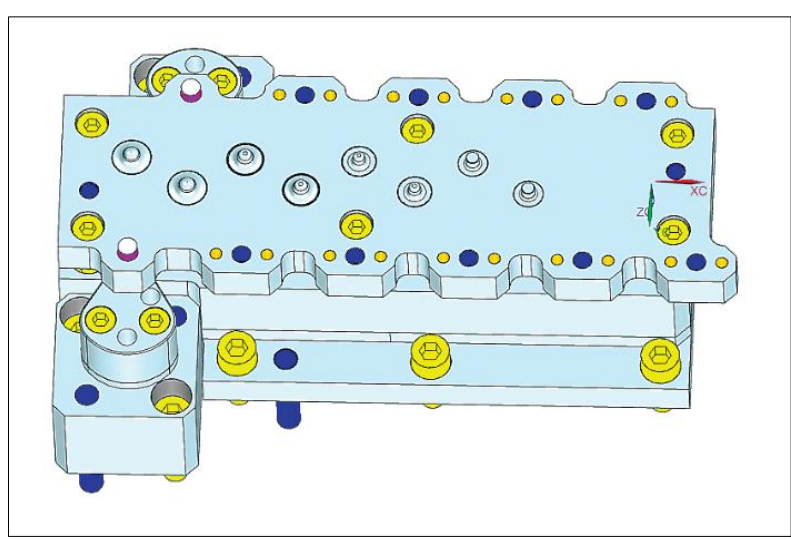

Fig. 5. First upper part

(from the first to the fourth tact)

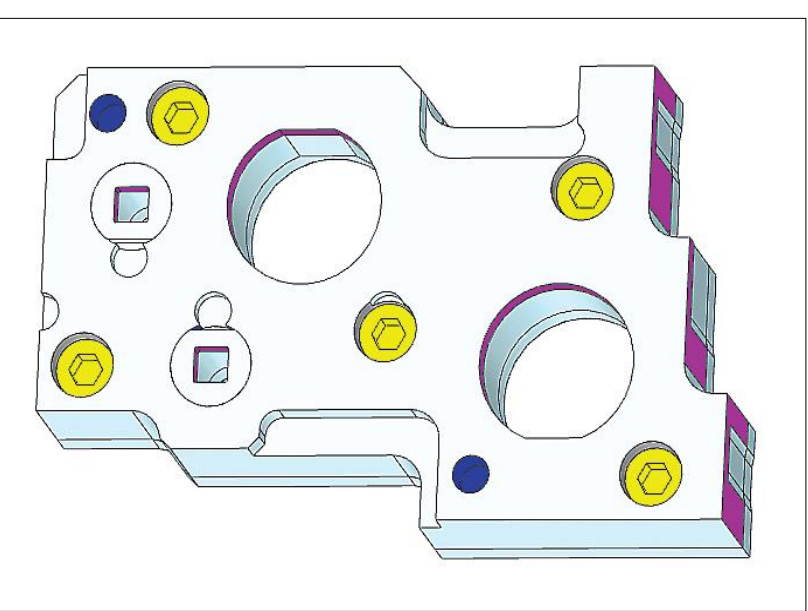

Fig. 8. Second lower part

(from the fifth to the ninth tact)

\section{Numerical analysis}

Initial assumptions for the drawing tool structure were verified by FEM analysis. The designed drawing tool was imported into the Simufact Forming software environment (fig. 9).

Due to the small rounding radii $(R=0.3)$ of the formed drawing, it was necessary to analyze the formation of this shape. Due to lack of space, it was limited to providing the final solution conditioning the fulfillment of dimensional requirements by the molding. 
Fig. 10 shows a set of punches and dies up to four tacts guaranteeing achievement of the assumed shape, and fig. 11 shows one of the obtained equivalent stress distributions in the first tact.

Results of numerical analysis indicated the need to use four consecutive tacts to shape the drawing. This solution enabled obtaining the required radii on the edges of the product. In addition, the risk of material cracking was reduced and the shaping forces were reduced, which increases the predicted tool life.

Introduction of the designed drawing tool under conditions of a large-scale industrial production confirmed the correct selection of the number of tacts and shapes of subsequent tools. Numerical calculations allowed for estimating the value of forces necessary to implement the entire process with a division into individual tacts. Determination of strength parameters makes it possible to reduce energy expenditure translating into the economics and competitiveness of production activities.

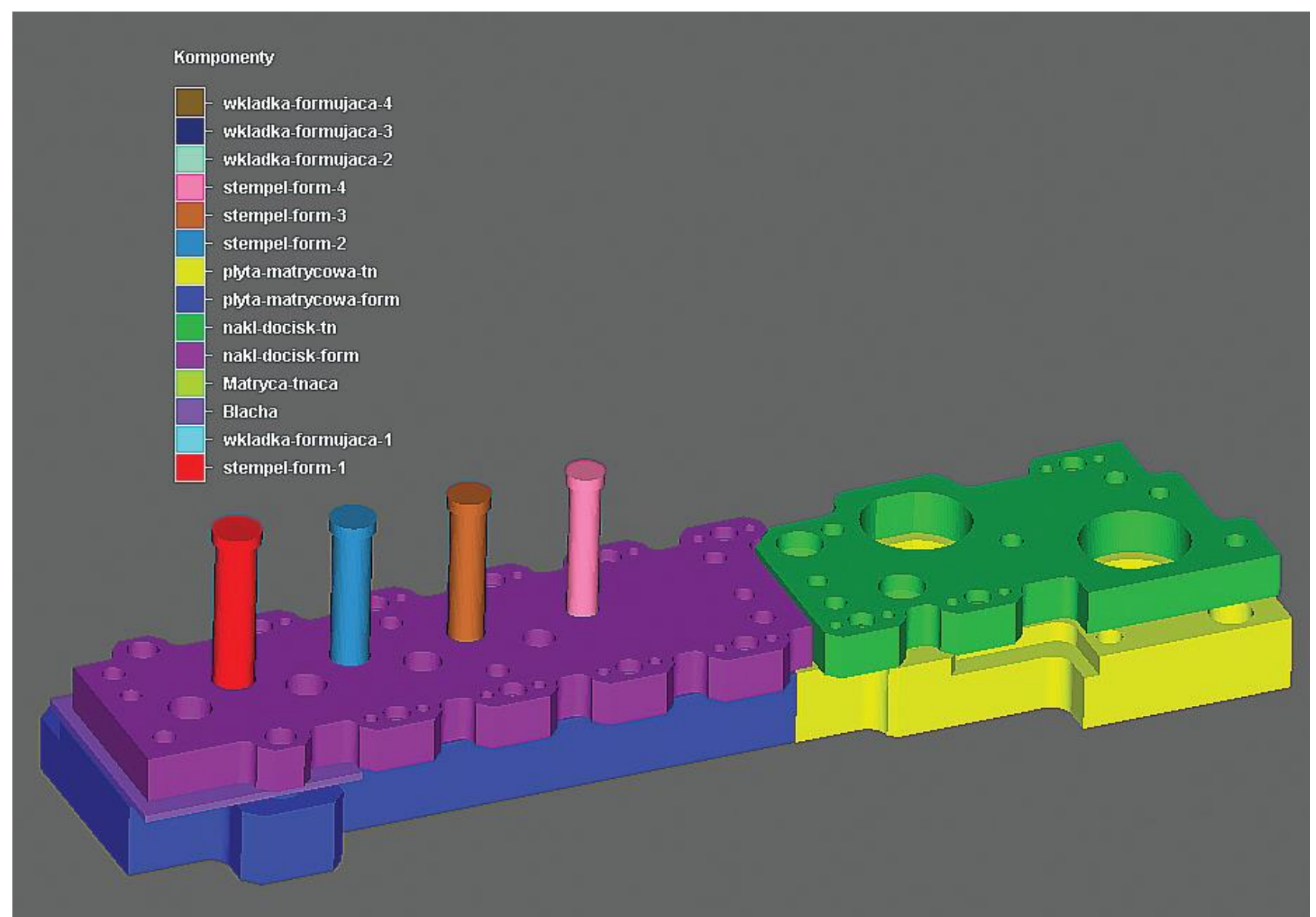

Fig. 9. Drawing tool model
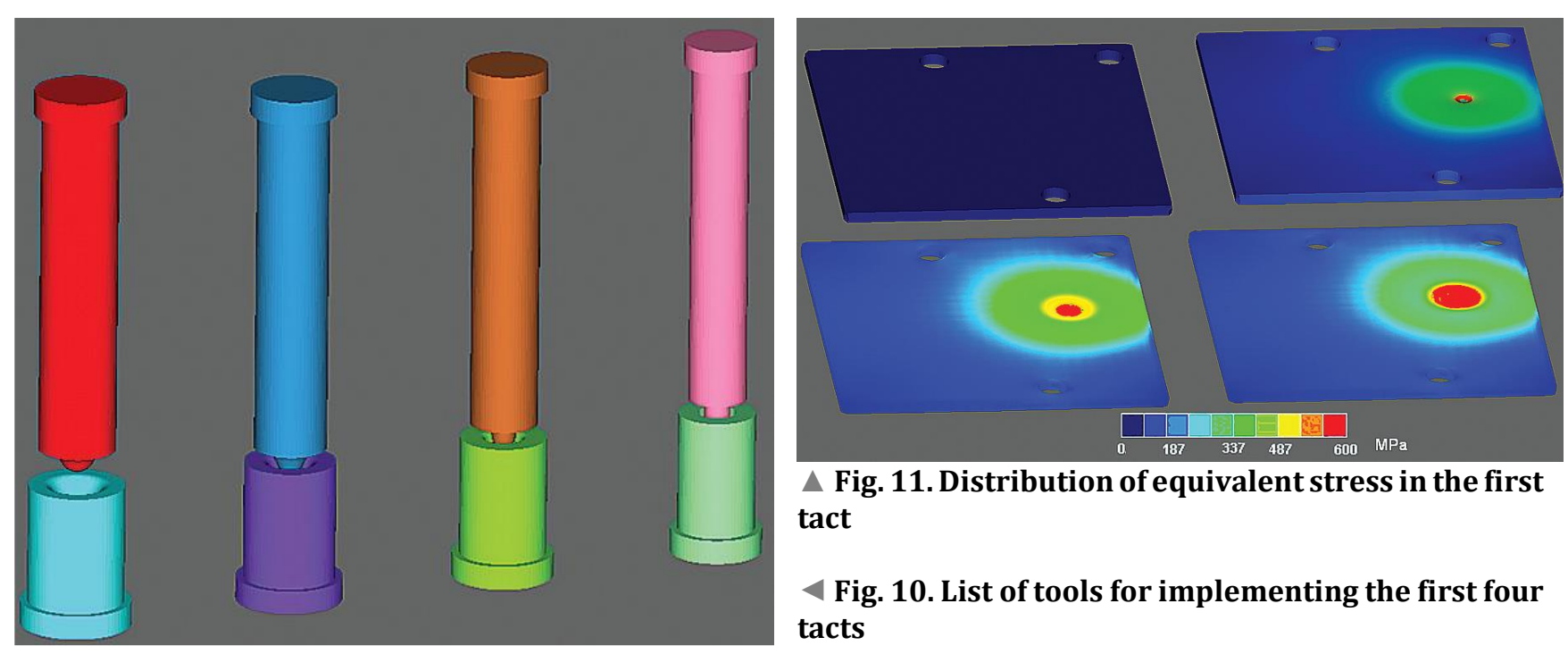

$\Delta$ Fig. 11. Distribution of equivalent stress in the first tact

$\triangle$ Fig. 10. List of tools for implementing the first four tacts 


\section{Summary}

The use of a modern FEM simulation tool in the design of a complex progressive drawing tool makes it possible to significantly shorten this stage and avoids errors that are difficult to foresee at the stage of adopting the design assumptions. Reduction of a tooling preparation time and constant demand pressure are reflected in the increasing use of FEM simulation calculations in plastic forming. Presented calculation example confirms the effectiveness of using modern CAX computer tools in the design of sheet metal drawing processes.

\section{REFERENCES}

1. Marciniak Z. „Konstrukcja tłoczników”. Warszawa: Ośrodek Techniczny A. Marciniak Sp. z o.o., 2002.

2. Markiewicz E., Wajda F. „Album konstrukcji tłoczników”. Warszawa: Wydawnictwo Naukowo-Techniczne, 1974.

3. Romanowski W.P. „Poradnik obróbki plastycznej na zimno”. Warszawa: Wydawnictwo Naukowo-Techniczne, 1976.

4. Romanowski W.P. „Tłoczenie na zimno”. Warszawa: Wydawnictwo Naukowo-Techniczne, 1974.

5. „Konstrukcja tłoczników”. Warszawa: Państwowe Wydawnictwo Techniczne, 1960.

6. Pater Z., Samołyk G. „Podstawy technologii obróbki plastycznej metali”. Lublin: Wydawnictwo Politechniki Lubelskiej, 2013.

7. Paquin J.R., Crowley R.E. “Die design fundamentals". $2^{\text {nd }}$ ed. New York: Industrial Press Inc., 1987.

8. Küttner R., Nekrassov G. "Development of an intelligent integrated environment for computer aided design of work holders". Proceedings NordDesign (2002). P. Boelskifte, J.B. Sigurjonsson ed. (14-16 sierpnia 2002) NTNU, Trondheim, Norway, s. 185-193.

9. Progressive Die Wizard Help, EDS 2003. 